\title{
INTERthesis
}

Revista

Internacional

Interdisciplinar INTERthesis

\section{INCENTIVES TO FAIR TRADE CERTIFICATION: THE CASE OF ORANGE PRODUCTION IN THE STATE OF PARANÁ, BRAZIL ${ }^{1}$}

\author{
Sandra Mara Schiavi Bánkuti ${ }^{2}$ \\ Ferenc Istvan Bánkuti ${ }^{3}$ \\ Melise Dantas Machado Bouroullec ${ }^{4}$
}

\begin{abstract}
The authors believe that contemporary challenges related to sustainable rural development planning and food security are encouraging experiments with new models of rural development that includes Fair trade arrangements. The article is based on the outcomes of a case study of motivations to adopt these arrangements among orange cultivators located in the state of Paraná, in South Brazil. These arrangements are seen as an alternative, successful strategy for the small-scale farmers located in this area. The evidences confirm that the main impulse to make use of this kind of certification is related to expectations of improvements in quality of life for producers and their families. Regular access to markets was assumed as one important economic feature. From the environmental perspective the certification process allows too for coherent enforcement of the established regulations and also for the strengthening of so-called "good practices". Otherwise, monitoring reveals the emergence of several obstacles due to cultural factors and to working contingencies. Bureaucratic control of the certification dynamics was considered rather as a positive factor of improvement of the whole productive system.
\end{abstract}

Keywords: Fair trade certification. Sustainable orange production. Perception of social and ecological impacts of Fair trade certification. Territorial development. Local agri-food systems.

\footnotetext{
${ }^{1}$ Este artigo foi apresentado oralmente no VI Congresso Internacional Sistemas Agroalimentares Localizados - os SIAL face às oportunidades e aos desafios do novo contexto global em maio de 2013 na cidade de Florianópolis, SC, Brasil.

${ }^{2}$ Doutora em Engenharia da Produção pela Universidade Federal de São Carlos, São Carlos, SP, Brasil. Professora do Departamento de Administração na Universidade Estadual de Maringá, Maringá, PR, Brasil. E-mail: smkbankuti@uem.br

3 Doutor em Engenharia da Produção pela Universidade Federal de São Carlos, São Carlos, SP, Brasil. Professor do Departamento de Ciência Animal da Universidade Estadual de Maringá, Maringá, PR, Brasil. E-mail: fibankuti@uem.br

${ }^{4}$ Doutora em Engenharia da Produção pela Universidade Federal de São Carlos, São Carlos, SP, Brasil. Professora da Ecole d'Ingénieurs de Purpan, Department of Economics, Management and Marketing, Toulouse, França. E-mail: melise.bouroullec@purpan.fr
}

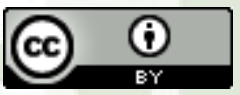




\section{Introduction}

Global market context reflects the liberalization of exchanges and the reorganization of production functions, especially considering fusion and acquisition processes between agents in agri-food chains. In such context, questions related to rural development, food security and environmental perspectives have emerged. To face global market perspective, as emphasized in Muchnik (2009), a new model for agricultural development has emerged all over the world, considering changes in rural society (social tissue, organization, coordination and plurality), environmental issues, biodiversities, product differentiation, product quality and food safety. As stressed in Boucher and Gonzales (2011),

\footnotetext{
Podemos entonces resumir el problema del sector rural, en particular para las agroindustrias rurales en un nuevo desarrollo a partir del nuevo contexto económico: posicionarse en los mercados globalizados; es decir, mantenerse en los mercados localizados compitiendo con los nuevos actores extranjeros, o buscar insertarse en nichos de mercado en el extranjero (BOUCHER; GONZALES, 2011, p. 75).
}

We understand Fair Trade as an alternative to producers to face recent global context. As emphasized by Rincón et al. (2005),

[...] o Comércio Justo se propõe a ser alternativa concreta ao atual sistema de comércio global, em que o pequeno produtor fica à mercê do poder econômico que domina as regras do "livre mercado" e não há preocupação com as condições de vida de seus fornecedores. Além do pagamento justo e estável pelo produto, o Comércio Justo tem como objetivo o desenvolvimento sustentável da comunidade de produtores, tanto no aspecto socioeconômico, quanto no que diz respeito ao meio ambiente (RINCÓN et al, 2005, p. 9).

It is also important to highlight the importance of Fair Trade for rural development. Rural development is intrinsic to Fair Trade idea in Brazil, related to an endogenous process. In that sense, capacity of producers and other investments arising from extra payment allow regional and rural development.

According to World Fair trade Organization (WFTO) and Fair trade Labelling Organization International (FLO) (2009, p. 6), one can understand Fair Trade as "[...] a trading partnership, based on dialogue, transparency and respect, that seeks greater equity in international trade". According to them, Fair Trade seeks to 
warrantee better conditions to marginalized producers and works, promoting rural development.

Ipardes (2004) emphasized orange production as an alternative for small farmers in Paraná, specifically in the northern region. According to the same source, soil and climate conditions and land structure based on small areas has turned orange production into a relevant activity in the region.

Strategies for orange production, according to Neves (2010), are related to cost leadership, differentiation and diversification. Considering low-scale production and resources limitations, specifically concerning labour force and land, differentiation turns out as an important mechanism for small producers, which includes certificated production. Tupy, Mancineli and Costa (2009), for instance, showed the importance of Fair trade certification to implement market development strategy, and reach new markets for by small-scale fruit producers in Brazil.

Considering challenges for Brazilian orange chain, such as better relationship among agents along the chain and the accomplishment of sustainable prerequisites for final products, as highlighted by Lohbauer (2011), as well as vertical integration and market concentration, Fair trade certification can be a notable way to surpass such problems, specifically concerning small farmers, as in Paraná state. In such situation, the following question emerges: what is the configuration of Fair Trade orange production in the Northern Paraná, Brazil?

Thus, the aim of this paper is to comprehend Fair trade certification process for orange production in the Northern Paraná, specifically concerning a cooperative of rural producers in Maringá/PR. Specific objectives include the investigation of external and internal motivations to certification, as well as results and difficulties related to such process.

This paper is organized as follows: besides this introduction, section 2 comprises the methodological procedures for this research; results are detailed in section 3, considering description, discussion and analysis; the fourth section consists of final remarks.

\section{Methodological procedures}

According to Kalof, Dan and Dietz (2008), qualitative research focuses on the meaning and motivations basing cultural symbols, personal experiences and 
phenomena, as well as on detailed comprehension of social world processes. In this case, qualitative research comprehends a descriptive study on the subject (GIL, 1999). Methodological procedures involved data collection and analysis. To support research, secondary sources of information were used in two ways: theoretical foundation was used to guide the study, concerning LAFS (Local Agri-Food Systems) and SCP (Structure - Conduct - Performance) paradigm. Framework proposed in Muchnik (2009) was used, as well as Industrial Organization theory, considering SCP paradigm. Also, information about Fair Trade and orange production in Brazil and Paraná helped to support the study and complement information. Directly concerning research object, secondary data about the cooperative were obtained through articles, press releases, documents, annual reports and other institutional materials.

Methodological procedures also involved primary data collection through indepth interviews (KALOF; DAN; DIETZ, 2008), with two cooperative representatives, engaged in Fair Trade certification. From here on, they will be quoted as Respondent 1 and Respondent 2. Interviews were recorded and transcript. Finally, data were analyzed through content analysis method.

\section{Results and discussion}

Since secondary data were essential to construct this paper, results include the theoretical foundations of research, specifically concerning LAFS approach and SCP paradigm. Also, we bring a brief discussion on Fair Trade and orange sector in Brazil.

\subsection{LAFS approach under the lens of SCP paradigm}

During the 90's, a discussion concerning Localized Agri-Food Systems (LAFS) begun in France. As mentioned in Boucher and González (2011, p. 13),

un SIAL es un sistema que integra organizaciones diversas de produccion y de servicio, vinculadas por sus caracteristicas y funcionamiento a un territorio especifico, de tal forma que los componentes (productos, personas, instituciones, sus relaciones, etc.) se combinan en una organizacion agroalimentaria bien definida y reconocida. 
According to Muchnik (2009, p. 04), LAFS began to be interpreted, on one side, "as a group of visible agri-food activities that are territorially established", which is more positivist, and on the other side, as an approach in a more flexible point of view, "a way of handling the development of local resources, even if the 'system' does not exist as such". The latter is which better fits this paper.

It is remarkable to consider the importance of interdisciplinary perspective in LAFS approach: its consideration is connected to different ideas, as clusters and SPL, agri-food systems, sustainability, competitive advantages, anthropology and consumption behavior, among others. Considering its interdisciplinary, this paper searches for combining LAFS approach to Structure-Conduct-Performance (SCP) paradigm, from Industrial Organization branch of Economics.

SCP paradigm was seminally discussed by Edward Mason, in the 30's, and formalized by Joe Bain, in the 50's decade. From that time on, many studies have discussed the relations between market structure, firms' conduct and performance. Scherer and Ross (1990), for instance, explain the non-linear interactions between components: according to the authors, external aspects related to basic conditions and public policies interfere in market functioning. Moreover, they emphasize strong relations between market structure, conduct and performance, since conduct can change market structure (and vice-versa) and performance can influence on conduct (and vice-versa), showing that relation among the three are not unidirectional (see Figure 1). Such idea, widely disseminated in the area, gives to firms' conducts an active role, meaning a central importance to company's strategies. 


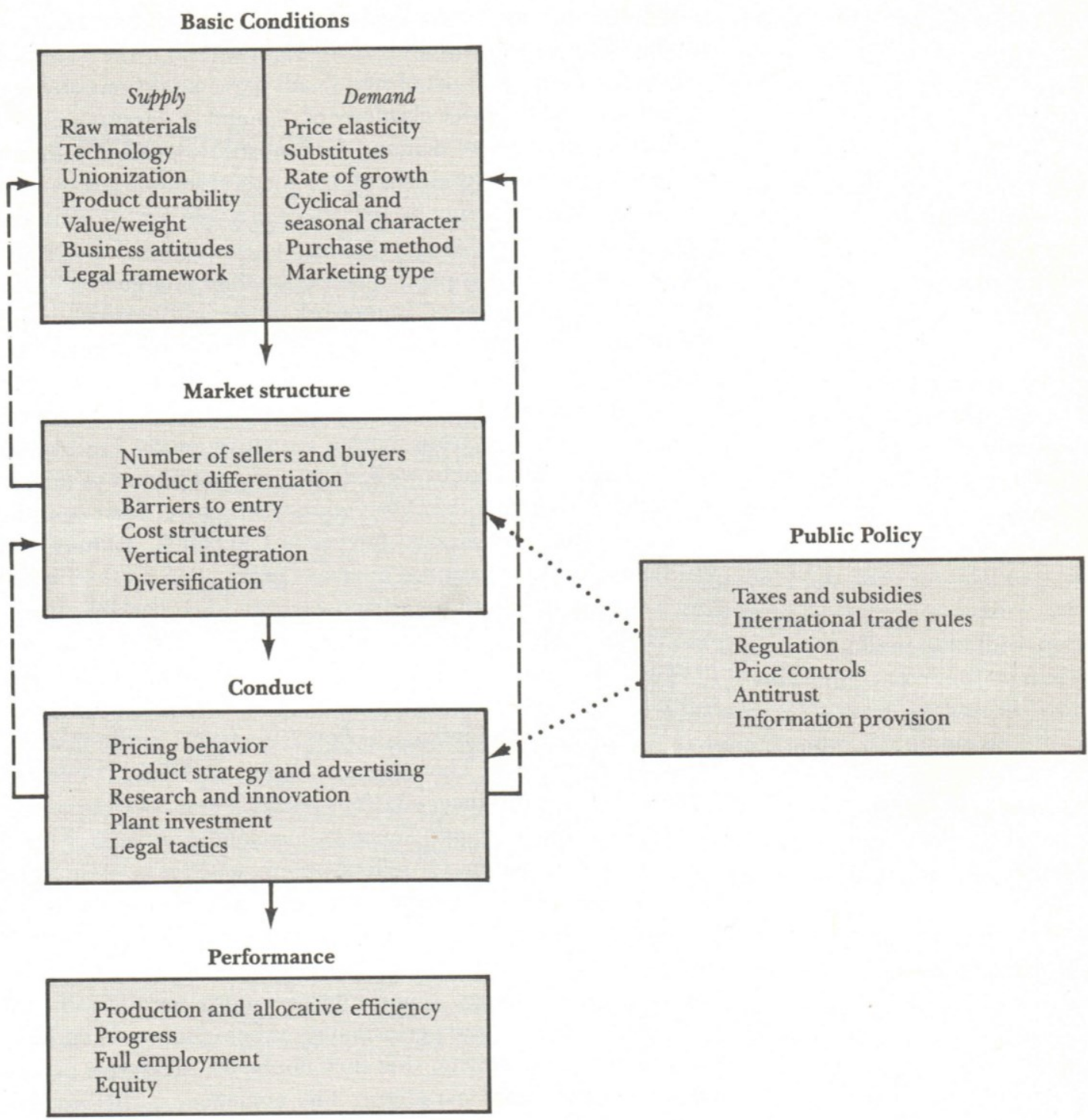

Figure 1 - Structure-Conduct-Performance Paradigm.

Source: Scherer and Ross (1990)

Considering the LAFS process of localization/delocalization, proposed in Muchnik (2009), both models could be overlapped, as in Figure 2. One can consider global market context and challenges as basic conditions, since they are connected to general changes, for all agri-food chains. Market structure is mainly related to sectorial developments, comprising in LAFS approach market public policies. Local strategies, developed to face global context and sectorial features are understood as conduct, in this case not developed individually but in-group (collective action). Finally, results in terms of performance are understood as localization or delocalization of activities. 

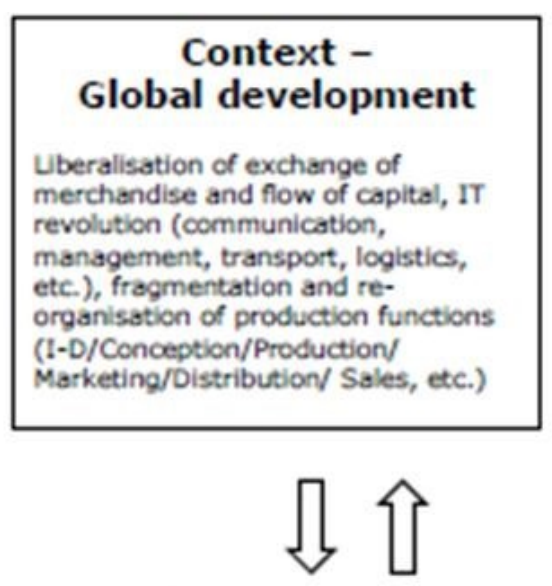

\section{Sectorial Developments}

(Public policles, rules and regulations, technological changes, subsidies, clearings, etc.)

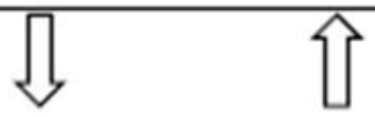

\section{Local strategies}

(Projects, innovation dynamics, organisation, collective actions, etc.)
Basic Conditions
Environment, development of rura societies, food security and food quality, etc.)

\section{Market Structure}

\section{Conduct}

\section{Performance}

\section{Territorial Dynamics}

Localisation/delocalisation of activities

(Historic-cultural links; material links, immaterial links, etc.)

Figure 2 - Localization/ delocalization of agri-food activities under the lens of SCP paradigm. Source: Elaborated from Muchnik (2009) and Scherer and Ross (1990)

Specifically concerning this research, the focus is on local strategies to face sectorial developments and global context, concerning the adoption of Fair trade certification as a project to face orange sectorial dynamics, market challenges and opportunities. Besides that, we aim to identify which results are mainly highlighted in that context, concerning economic, social and environmental aspects.

\subsection{The orange sector in Brazil and Paraná}


Brazil is the most important orange producer in the world. According to FNP (2012), Brazil produced 21.6 million tons of orange in 2010/2011 harvests, which corresponded to more than $39 \%$ of world production.

According to MAPA (2013), about $50 \%$ of orange production in the world is directed to orange juice processing; in Brazil, such proportion reaches $80 \%$. The country is also the most important producer and exporter of orange juice: in 2010/2011, Brazilian orange juice production reached 1.475 million tons, representing $60 \%$ of world production; for the same period, Brazilian exports corresponded to 1.210 million tons, representing $77 \%$ of total orange juice exports (FNP, 2012). The main orange juice importer is the European Union (EU), absorbing more than $53 \%$ of world imports, followed by the United States, Canada and China (FNP, 2012). The main destinations of Brazilian orange juice are Belgium, Netherlands and United States, comprising together $50 \%$ of Brazilian frozen orange juice exports (FCOJ), and $88 \%$ of non-frozen orange juice (FNP, 2012).

Regarding consumption, Brazil is an important consumer of oranges, being responsible for 6.079 million tons in $2010 / 2011$ harvests (21\% of world consumption), followed by China and EU. Concerning orange juice consumption, on the other side, Brazil is not a great consumer: the country in the $7^{\text {th }}$ in world rank, absorbing $2 \%$ of total consumption. EU and United States are the most important consumers, corresponding to $77 \%$ of total consumption in the world (FNP, 2012).

In Brazil, São Paulo is the most representative state in orange sector: about $77 \%$ of Brazilian orange production in 2011 was in that state (FNP, 2012). Moreover, industries are mainly localized in São Paulo, specifically in Central and Northern region of the state. Paraná is not an important state in orange production, being the $5^{\text {th }}$ in Brazilian rank, with $4 \%$ of national production (IBGE, 2012).

Orange production in Paraná is mainly concentrated in the Northern region, comprising Northwestern, Central North and "Norte Pioneiro" (see Figure 3). Although, orange production does not correspond to one of the most important products in Paraná's agriculture, comprising $0,44 \%$ of total GPV, it responds to the first in the group "fruit", representing more than $36 \%$ of value in that group. Besides that, it involves other relevant aspects: orange production concerned 27,143 hectares in 2011, adding a value of $R \$ 234$ billion (IBGE, 2012). Moreover, it included in 2006 1,704 rural farms, from which $72.4 \%$ are small ones (less than 50 hectares) (IBGE, 2009). 


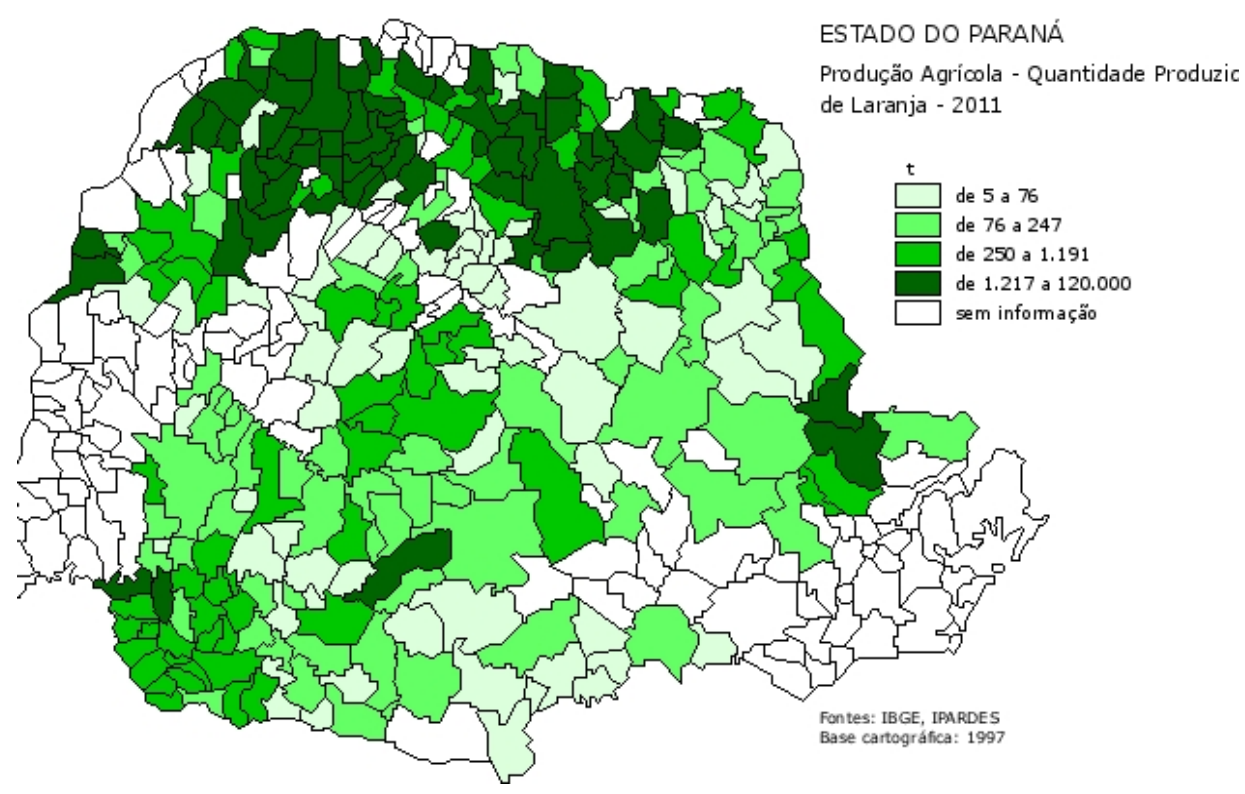

Figure 3 - Orange production in Paraná state -2011.

Source: IPARDES, 2013a

Moreover, some attention must be given to orange production in Paraná, specially due to some facts: (i) in 2006 , orange activity employed 2,300 people and occupied more than 1,500 family workers in Paraná (IBGE, 2009); (ii) production in the state almost doubled from 2006 to 2011, reaching 784.5 thousand tons; (iii) South region of Brazil is considered an opportunity for the expansion of orange production in Brazil (NEVES, 2010); and (iv) processing companies are aware of orange production in Paraná, and in 2012, multinational Louis Dreyfus Commodities was settled in the state.

Considering agri-system, MAPA (2013) highlights the organization and coordination as important factors to Brazilian orange chain competitiveness. Neves and Trombin (2012) report the concentration along the global chain, specifically concerning bottling and retailing segments: according to authors, $52 \%$ of processed orange juice in the world is bottled by the biggest ten bottling companies. Concerning retail: "[...] em países importantes para o suco de laranja, observa-se que as vendas são concentradas em poucos varejistas" (NEVES; TROMBIN, 2012, p.11).

In the same direction, processing segment in Brazil is focused on concentration through acquisition and fusion strategies: according to Senhoras, Takeuchi and Takeuchi (2006), concentration rate CR4 for orange juice industry in São Paulo state (most important region in the sector) increased between 2000 and 2004, from 0.67 to 0.914 . It is important to mention that four companies - Citrosuco, 
Cultrale, Louis Dreyfus Commodities and Citrovita - are the biggest ones, dominating the sector. Neves (2010) stressed industry concentration as an important trend in the Brazilian orange sector. Also, about $30 \%$ to $35 \%$ of orange supply is vertically integrated, which increases bargaining power of industries face to small producers.

\subsection{Fairtrade certification}

Fair trade sales represent in the world only $0.1 \%$ of international trade. Nevertheless, it is in ascendance, showing a 12\% increase between 2010 and 2012. Products are sold in more than 66 countries, involving more than 1.2 million producers and workers. Europe corresponds to $65 \%$ of market, and United Kingdom, German and France are the most developed consumer countries (FLO, 2013).

Fair Trade was born from multiple humanitarian and activist initiatives in PostWar period. It is understood as a trade partnership based on dialog, transparency and respect. Such mode of trade seeks for equity in international trade. Fair Trade contributes for sustainable development through better exchange conditions and warranty of rights to marginalized producers and workers (MACHADO; PAULILLO; LAMBERT, 2006).

Fair Trade can be seen as a global network involving actors from developing countries (upstream activities) and developed countries (downstream activities, up to consumption). Main agents are the former, especially producers, as well as consumers willing to adopt that kind of trade and/or product.

A long process occurred form the act of some religious and NonGovernmental Organizations (NGO) in North America and Europe, to the formalization of Fair trade organizations. Since the beginning, the aim was to help poor communities to trade handmade product and increase income of those people. Some organizations started to structure trade chains and spread products through specialized stores, while others promoted Fair Trade concept by putting it on International Trade agenda and discussing negative effects of conventional trade for developing countries (LAGENTE, 2005).

In some cases, integrated chain has evolved, being currently composed by producers organizations (small producers and hired labor ones), which sell their products via traders agents specialized in such market. Sales are achieved through specialized stores ("world shops"), frequently concerning the existence of national 
Fair Trade federations, which are responsible for store networks and relations with public power.

In the case of non-integrated chains, distribution agents (exporters, importers, processing units, retail, etc) are not necessarily specialized in fair trade. Thus, each agent needs to be certified, in order to warranty consumers the origin and consequent benefits of products (REDFERN; SNEDKER, 2002).

To coordinate activities emerging from different certification initiatives, in 1997 Fair trade Labelling Organization International (FLO) was created. The aim was to increase efficiency and effectiveness of certification systems through the synchronization of approaches and control costs reduction. In 2003, "Fair Trade" label was adopted. FLO is responsible for developing fair trade standards, and audits are accomplished by an independent entity, FLO-CERT, credited ISO 65 in 2008.

In Fair Trade chain, each certified product has a minimum price, to protect and mitigate risks for producers. It is also defined a premium (US\$100 per ton of orange juice, for example), which must be directed to investments on priority fields for producers or workers, such as health, education, environment, productive factors, etc.

In Brazil, Fair Trade begun in the 70's through the integrated chain model. Certified chain started in the country in 1998 (BOUROULLEC, 2010). Orange juice and coffee producers were the first to get certification.

Specifically concerning orange chain, Fair Trade chain includes production, processing, trading (selling out and buying), packaging, transforming and branding (see Figure 4). According to FLO-CERT (2013a), there are in Brazil five organizations certificated on Fair trade in orange producer segment, being two in Paraná and three in Rio Grande do Sul, both states in the South region of Brazil. Paraná has one of the two traders certified by FLO, in the Northwestern region of the state. 


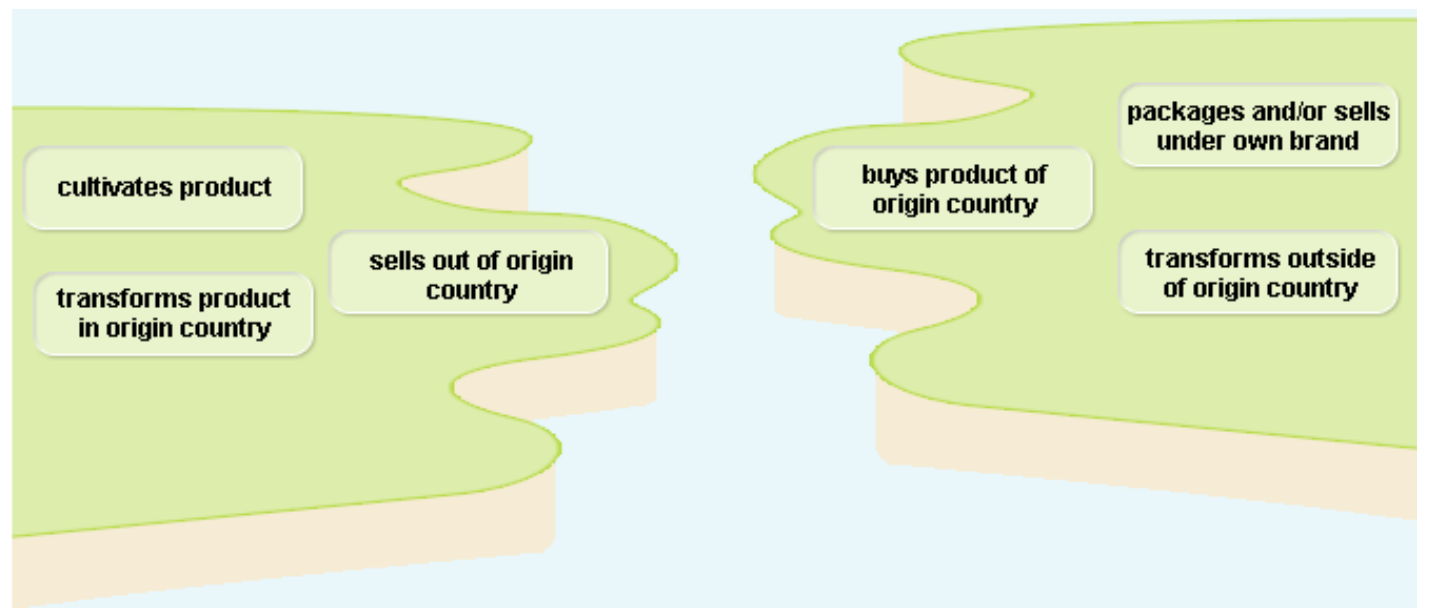

Figure 4 - Fair Trade orange trade chain.

Source: FLO-CERT (2013b)

\subsection{The case of a cooperative in Maringá/PR}

The cooperative in study was born in 1963, directed to coffee production. In the mid 80's, the organization started commercial orange production in the Northwestern region. In 1994, they started in the processing segment, opening an orange juice unit in Paranavaí/ PR.

Nowadays, the organization encompasses about 11,000 producers, acting in North Paraná, with more than 50 operational units (see Figure 5). Diversification strategy is clear in the cooperative's history, although results are mainly related to grains and retail sectors. Group's revenues increased 70\% between 2008 and 2012, with special attention to citrus: orange revenues increased $179 \%$ in the same period, becoming the $4^{\text {th }}$ most important branch for the organization, after grains, retail products and agricultural inputs.

Specifically concerning orange activity, some factors are noticed. Since 1999, the company has been involved in Fair Trade orange chain, with FLO: until 2012, it processed oranges from certified producers, in their processing unit in Paranavaí/ PR. Recently, they strategically changed their participation in trade chain. At the same time they sold the processing unit to Louis Dreyfus Commodities (LDC), a French-based multinational agri-food company, they were certified as a small producer organization by FLO-CERT. According to the organization, lack of competitiveness in industry segment and the need for high investments in processing plant directed to focusing on producer segment, organizing it and giving assistance to orange producers. 
Also, it is important to mention a partnership with another cooperative in Central North Paraná, begun in 2010, which included the leasing of an orange processing unit in Rolândia/PR, involving orange producers in six thousand hectares (ha) of orange area. Oranges produced by co-operators are processed in two plants in the region (marked in orange in Figure 5), being the Northwestern unit certified on Fair trade.

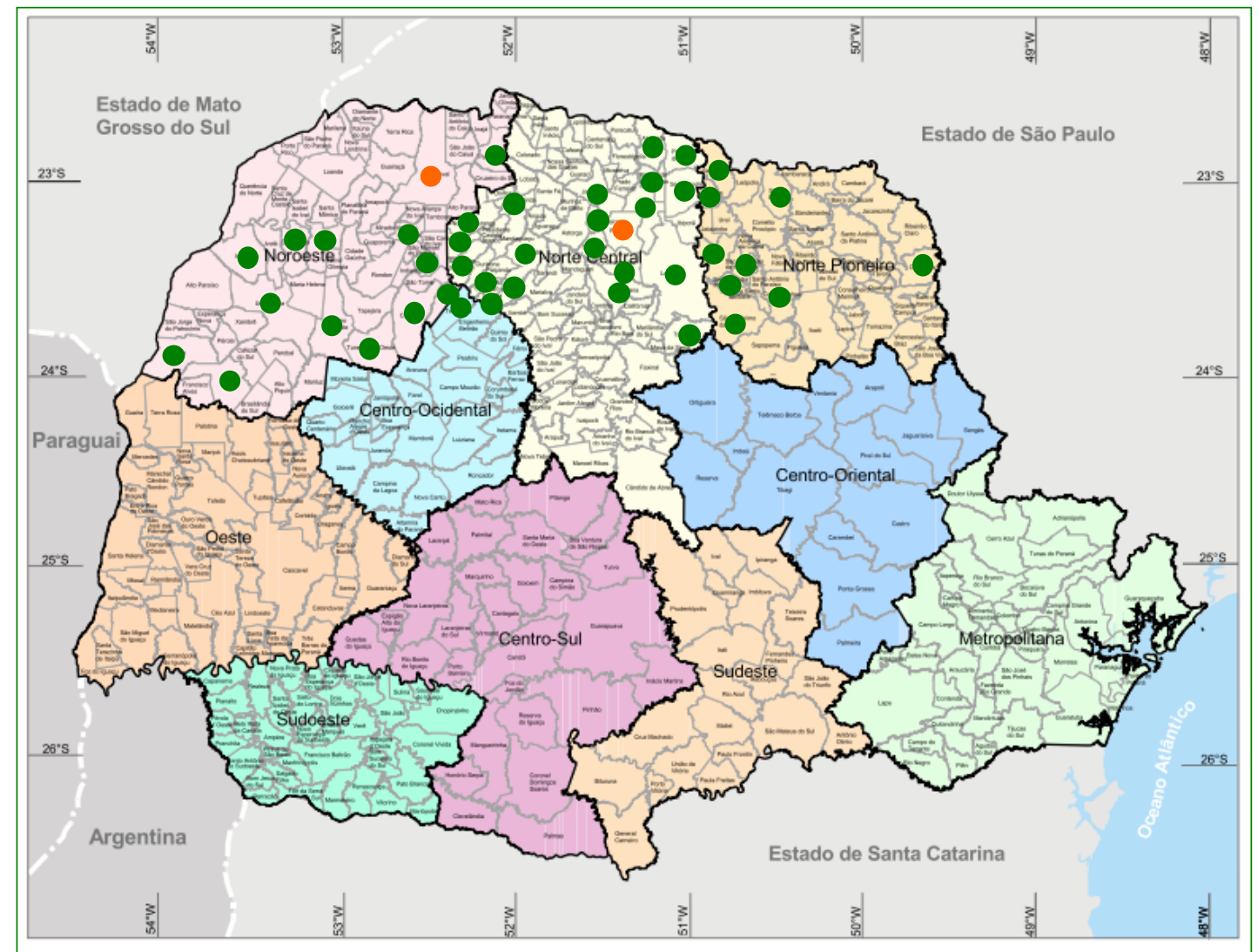

Figure 5 - Cooperative's units in Paraná.

Source: Elaborated from IPARDES (2013b) and Field Research (2013)

According to interviews, cooperative comprised about 300 to 310 orange producers by the end of 2012, producing 9.5 million boxes of oranges $(40.8 \mathrm{~kg})$, which corresponds to 387.6 thousand tons. About $85 \%$ of it $(8.0$ million boxes of oranges) was directed to the industry, to conventional and Fair trade orange juice. Specifically concerning Fair trade, there were 178 co-operators certified on Fair trade: 64 in Paranavaí region and 114 in Rolândia region. Fair trade orange is directed to frozen concentrated orange juice (FCOJ), exported by LDC to Europe. Although the proportion of orange directed to Fair trade juice was not informed, Ribeiro (2013) highlighted that it corresponds to less than $10 \%$ of orange processed by LDC coming from that organization in 2012/2013 harvest. 
Fair trade production area comprises 2,167 hectares (ha) in both regions (1,042 ha in Paranavaí and 1,125 ha in Rolândia). It represents an average of 16.28 ha of orange area per producer in Paranavaí, and 9.68 ha in Rolândia. Considering total area (not only directed to orange), farms' average sizes are, respectively, 33.6 ha and 26.4 ha. It makes clear the diversification of co-operators, aligned to cooperative strategy. There is no producer at all only dedicated to orange production; most of them produce grain (chief product for the organization). It is important to mention that edaphoclimatic conditions in Paranavaí region limit rural activity. As highlighted in IPARDES (2004, p. 11), "a formação arenito Caiuá, associada ao clima da região, deu origem a solos com sérias restrições ao uso agrícola, pela suscetibilidade à erosão hídrica e eólica e à baixa fertilidade". Thus, grain production is generally restricted to corn and wheat in the region. Moreover, many orange producers in Paranavaí region have citriculture as their main activity, due to resources conditions.

Orange transaction between producers and LDC is made through a long-term standard contract, settling price, which is the same for Fair trade and non-Fair trade producers. According to interviews, fixed price is negotiated every three years, and it brings a good situation for produces, since it mitigates risks related to market oscillations and allows stability. Nowadays, price is fixed in US\$ 4.8 each $40.8-\mathrm{kg}$ box. For Fair trade producers, main motivations are related to training and courses concerning adequacy in farms.

As for premium payment, value corresponds to US\$100 per ton of orange juice, according to FLO table; in both interviews, emphasis was given to the importance of investing in orange chain improvement and sustainability. According to Respondent 2, "o Fairtrade visa uma questão que é base: é preciso ter volume para ter negócios, e deve-se investir na cadeia”. In this sense, it was possible to observe the disposition to use the premium to improve orange farmers' conditions, searching for adequacies of non-conformities pointed out during FLO audits (first audit in 2012 pointed three non-conformities).

Main motivation is internal, related to social aspects: respondents emphasized the premium as the initial incentive for Fair Trade certification, linked to the possibility of improving social projects by the cooperative. When they acted in processing segment, they couldn't use that money for improving producers' conditions, since premium payment goes to producer organizations. As Respondent 1 mentioned: 
"Com a certificação de processadora, eu não posso fazer nada pelos meus produtores. Eu tenho requisitos a cumprir, mas não consigo apoiar meu produtor". So, they were Fair trade, but they didn't act straight with co-operators. Now, they can use premium directly in orange activity, through joint actions. Resources are mainly applied in courses and training activities for orange producers, in order to develop the activity and enhance in Fair Trade requirements. According to Respondent 2, "aceitar o benefício coletivo depende da inclusão do indivíduo". He also emphasized Premium hadn't been used yet (until the moment of interview), but projects were being discussed with producers and FLO.

By the time cooperative decided to certificate production, an auditor was hired to discuss the benefits of Fair trade investments and projects. Now, that person is also responsible for helping consultants with producers' adequacies. In this sense, Fair trade certification brought to the organization a great sense of orange production processes, and a consequent higher process control in farms. Respondent 1 sees it as a positive aspect from the organization's perspective, and by Respondent 2, from producers' point of view, since they have the opportunity to develop orange activity, which will bring long-term results. As mentioned: "o produtor deve entender os benefícios da adequação. Por exemplo: se ele fornecer conforto ao trabalhador, ele tende produzir mais, e vai render mais". Developing projects to use the premium also requires careful attention to producers' and workers' needs. "Existe uma lista muito grande de sugestões da FLO, para melhorar a cadeia, para adequações. Ainda precisamos investigar mais sobre as duas realidades que temos: o produtor e o trabalhador da citricultura." (Respondent 2)

Some projects were indicated by Respondent 2, as follows: (i) visit program to Florida, to provide to a group of producers contact with an important orange belt in the world, including industry and farm visitations, lectures and contact to American orange producers; (ii) training courses related to social and environmental good practices, directed to open producers' mind; (iii) courses concerning specific subjects, such as the use of personal protective equipment (PPE) by workers; and (iv) projects concerning rural rest areas for workers, involving infrastructure investments. It is important to mention that direct investments will not be made from the premium payment. As stated by Respondent 2 "são projetos de educação, mas não de investimento direto". 
Moreover, an important indirect social result is related to family succession, since certification encourages children to keep on the activity, preventing rural exodus. It is not in the normative, but it is implicit. In this case, Respondent 1 highlighted that "temos que mostrar aos jovens que eles também podem crescer no campo. O Fair trade, ao proporcionar novas oportunidades faz os jovens repensarem a produção agrícola, pois há chances deles se manterem". Nevertheless, rural activity seems to be legitimated through certification, as pointed during interview: "Há também um bloqueio cultural - 'campo é coisa de caipira', então é preciso renovar o conceito, e o Fairtrade ajuda nisso" (Respondent 1). Finally, respondents mentioned that producers face the opportunity of being valued, receiving attention from the organization (training, courses, visits, etc.), which generates positive feedbacks.

Considering economic and environmental aspects, results showed that they are also important, although not central. Access to market and assurance of production sale were mentioned as important economic results of certification. Environmental adequacy in rural farms and the maintenance of good environmental practices were also identified as an important effect.

As for orange production in the region, Respondent 1 remembered orange is not an important product in Paraná's agenda; its importance in value is short. Nevertheless, for the organization, it is a commitment with producers: the role of the cooperative is to support producers in their activities; if they produce orange, the organization needs to answer their needs. Concerning this product, orange is strongly related to regional development, in Respondent 1's opinion; orange production is an activity that requires a little more support than other activities, especially for small producers. "Se não apoiarmos a laranja agora, ela vai morrer na região, como aconteceu com o café anos atrás." Moreover, "a rentabilidade é tão baixa, e os subsídios são tão poucos, que o pequeno produtor não tem como se segurar; se a gente não fizer alguma coisa agora, ele não fica na laranja, somente os grandes conseguem sobreviver" (Respondent 1). So, the importance of orange activity is connected more to social aspects, rather than economic ones. Figure 6 sums up main results of research, bringing motivation and impacts of Fair trade certification in the case.

Concerning limitations and challenges for certification, some aspects were stated. First the difference between processing and producer certifications. The former is simpler, mainly because it is related to the company's actions. The latter, on 
the other hand, is harder, because it involves a number of producers, with different points of view, and sometimes inflexible positions. So, part of the work depends on the organization, especially when it comes to bureaucracy. But, the most complex task is related to producers' non-conformities. In this sense, it is necessary to develop conscious ideas and change paradigms, which includes a deep work. According to Respondent 1, "lidar com a parte cultural é mais complicada, porque não tem receita".

Such cultural barriers were exemplified during interviews, as follows: (i) it is hard to convince a producer that is 15-year-old son cannot work, because she herself has worked since she was seven; (ii) when you mention the importance of specific areas for workers, minimally appropriate and comfortable, Respondent 1 mentioned that producers ask: "Ok, but where will I get the money for it?"; and (iii) concerning the use of prohibited pesticides, Respondent 1 told some producers used to say: "It is not dangerous, I've been using it for years and I am still alive". 


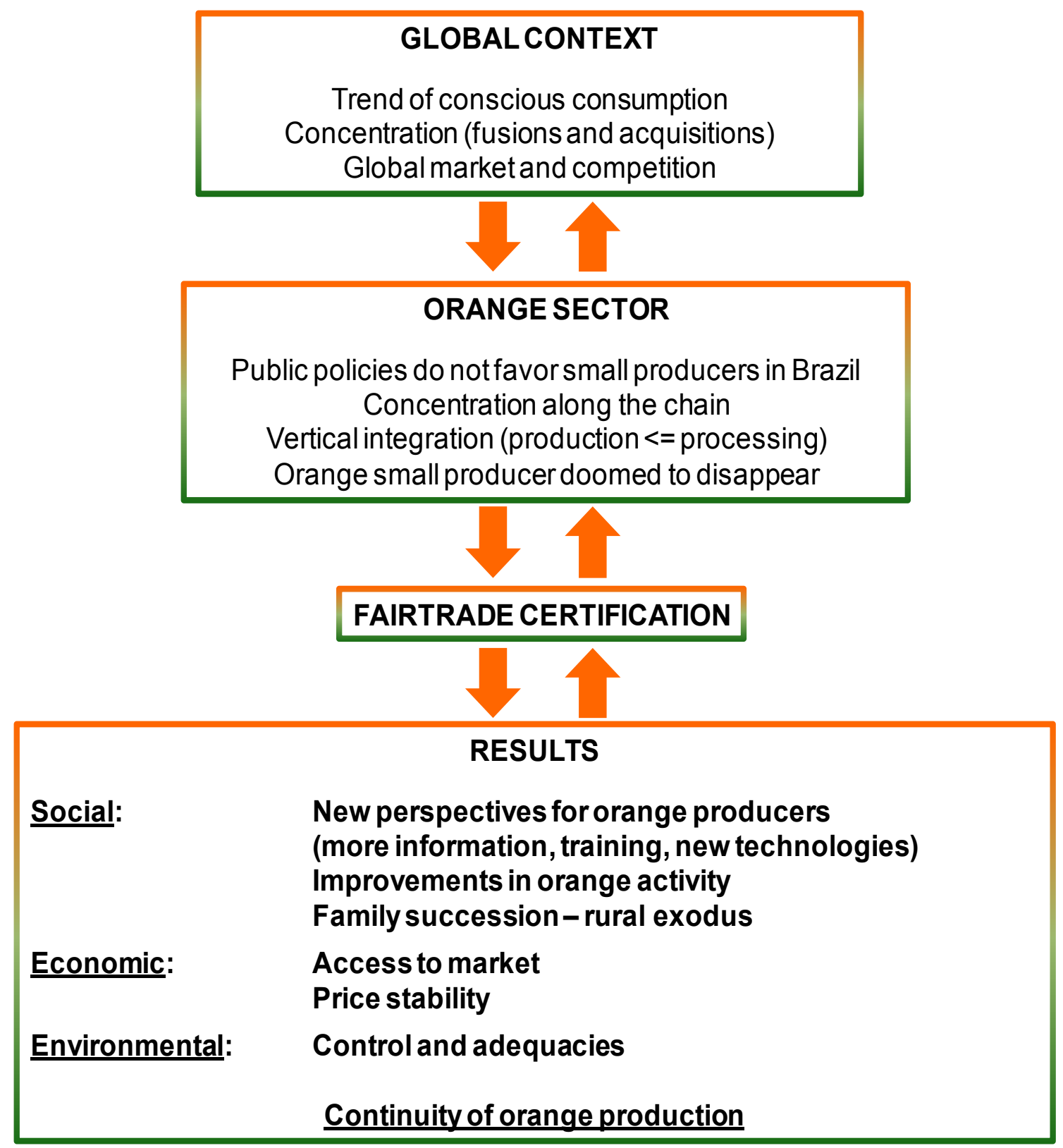

Figure 6 - Incentives and impacts of Fairtrade certification.

Source: Field research, 2013

In this sense, it seems that cultural aspects cause a negative pressure for Fair trade certification. It is especially true for social aspects: environmental adequacies are difficult, but recent discussions on "Código Florestal" in Brazil put producers in accordance to new paradigms. However, social adequacies are harder to be done, and requires an intense effort along with producers.

Finally, respondents believe that Fair trade certification is a good opportunity for agri-food chains in Brazil and in Paraná. Specifically concerning small producers, Respondent 1 mentioned the importance of spread information about Fair trade, with FLO assuming a crucial role in the search for such organizations. Also, considering 
Paraná state, the importance of cooperativism and the relevance of small-farm production, for several chains, make Fair trade certification a viable diversification strategy.

\section{Conclusions}

Fair trade certification can be seen as a mechanism to promote rural development and sustainable chain competitiveness. Considering SCP paradigm, we tried to understand linkages concerning external motivations (global context and sector dynamics), Fair trade certification, as a cooperative's strategy, and results from such strategy. We could observe a strong motivation derived from internal motivation, related to the possibility of using the premium payment for orange chain improvements.

In this case, Fair trade certification has brought good economic, social and environmental results, keeping small-scale production in the region and allowing financial resources to invest in improvements in orange activity. Thus, certification can be an alternative to face large-scale production in the region, keeping small producers in activity and promoting rural development. 


\section{INCENTIVOS PARA CERTIFICAÇÃO FAIRTRADE: O CASO DA PRODUÇAO DE LARANJAS NO ESTADO DO PARANÁ, BRASIL}

\section{Resumo:}

Neste artigo, a adesão aos princípios do Comércio Justo é entendida como uma alternativa promissora para os pequenos produtores rurais. Mais especificamente, a intenção é compreender o processo de certificação Fairtrade para a produção de laranjas na região norte do Paraná. Os resultados da pesquisa realizada indicam que a principal motivação para o engajamento dos produtores no Comércio Justo está relacionada à expectativa de usufruto de benefícios sociais decorrentes do ingresso no sistema. Isto, na medida em que o prêmio concedido estimula a melhoria das condições gerais de vida dos produtores e dos trabalhadores envolvidos. Ao mesmo tempo, contribui para assegurar a permanência dos filhos dos agricultores no meio rural, limitando assim o êxodo rural. A pesquisa mostrou ainda que os aspectos econômicos e ambientais são vistos como importantes, mas não centrais. O acesso regular a mercados foi mencionado pelos produtores como um resultado econômico importante deste processo de certificação - ao lado do reforço de práticas melhor ajustadas às normas ambientais vigentes e também da valorização de "boas práticas ambientais" nas propriedades. Por outro lado, a pesquisa revelou que as dificuldades mais importantes estão relacionadas a adequações sociais, especialmente no que diz respeito à existência de barreiras culturais e à gestão das condições de trabalho dos agricultores. O monitoramento burocrático do processo de certificação não foi visto como um problema, pelo fato de estar permitindo melhores condições de gestão dos processos produtivos. Os autores concluem que este processo tem gerado resultados econômicos, sociais e ambientais positivos na região.

Palavras-chave: Comércio justo. Produção sustentável de laranjas. Cooperativismo. Percepção de impactos da certificação Fairtrade Sistemas agroalimentares localizados.

\section{INCENTIVOS PARA LA CERTIFICACIÓN FAIR TRADE: ESTUDIO DE CASO DE LA PRODUCCIÓN DE NARANJAS EN EL ESTADO DE PARANÁ, BRASIL}

\section{Resumen:}

Los problemas relacionados con el desarrollo rural, la seguridad alimentaria y los aspectos medioambientales se han tratado en el contexto mundial. Frente a esto, se ha creado un nuevo modelo de desarrollo rural. Bajo esas premisas, los autores proponen un análisis del proceso de certificación para la producción de naranjas segundo las normas de Comercio Justo en el norte de Paraná, Brasil. La vinculación al sistema de Comercio Justo es vista como una alternativa novedosa para los pequeños agricultores. Se ha podido comprobar que la motivación principal de los agricultores investigados es interna, relacionada con aspectos sociales, pues el premio les permite mejorar sus condiciones de vida en el cotidiano. Además, la acreditación fomenta el mantenimiento de los agricultores en esta actividad productiva, evitando el éxodo rural y asegurando la sucesión familiar. Teniendo en cuenta los aspectos económicos y ambientales, los resultados confirman que estos también son importantes, aunque no centrales. Oportunidades de acceso a los mercados y garantías de comercialización han sido mencionados como elementos importantes en la evaluación. La adecuación ambiental de las propiedades rurales y 
el mantenimiento de buenas prácticas ambientales han sido también identificados como aspectos relevantes. Los obstáculos más importantes están relacionados con aspectos culturales y condiciones concretas de trabajo. El control burocrático no es considerado como un problema. En la visión de los agricultores, las normas oficiales fomentan mejores condiciones de evaluación y control de los procesos productivos. Se concluye que la adecuación a las normas de Comercio Justo ha generado implicaciones positivas en términos sociales, económicos y ambientales. Además de impulsar el desarrollo de la producción en pequeña escala al nivel local, este sistema ha favorecido la captación de nuevos ingresos para inversiones en la calidad de los procesos productivos.

Palabras-clave: Comercio Justo. Producción sostenible de naranjas. Sistemas agroalimentarios localizados. Cooperativismo. Percepción de consecuencias de la certificación Fair trade. 


\section{References}

BOUCHER, F.; GONZALEZ, J. A. R. Guia metodologica para la activacion de sistemas agroalimentarios localizados. IICA, CIRAD, REDSIAL Mexico-Europa. Mexico: IICA, 2011.

BOUROULLEC, M. D. M. Governanças Hibridas no Comércio Justo Citricola entre o Brasil e a Europa: arranjos institucionais complementares aos contratos. 2010. 219f. Tese (Doutorado) - Programa de Pós-Graduação em Engenharia de Produção, UFSCar, São Carlos, 2010.

FLO-CERT. Operators. 2013a. Available at: <http://www.flo-cert.net/flocert/29.html>. Access on: Feb. 15, 2013.

FLO-CERT. Scope of Certification. 2013b. Available at: <http://www.flo-cert.net/flocert/36.html>. Access on: Feb. 13, 2013

FNP. Agrianual 2013. Anuário da agricultura brasileira. Informa Economics / FNP South America. São Paulo, Sep. 2012.

GIL, A. C. Métodos e técnicas de pesquisa social. 5 ed. São Paulo: Atlas, 1999.

IBGE. Instituto Brasileiro de Geografia e Estatística. Censo Agropecuário 2006. Brasil e Grandes Regiões. Rio de Janeiro, 2009. Available at: <http://www.sidra.ibge.gov.br>. Access on: Jan. 20, 2012.

IBGE. Instituto Brasileiro de Geografia e Estatística. Produção Agrícola Municipal. 2012. Available at: <http://sidra.ibge.gov.br> Access on: Nov. 13, 2012.

IPARDES. Instituto Paranaense de Desenvolvimento Econômico e Social. Leituras meso regionais: Mesorregião Geográfica Noroeste Paranaense. Curitiba: IPARDES, 2004. 141p.

IPARDES. Instituto Paranaense de Desenvolvimento Econômico e Social. Base de dados do Estado. 2013a. Available at: <www.ipardes.gov.br>. Access on: Jan. 21, 2013.

IPARDES. Instituto Paranaense de Desenvolvimento Econômico e Social. Mapas. 2013b. Available at: <http://www.ipardes.gov.br>. Access on: Jan. 09, 2013. 
KALOF, L.; DAN, A.; DIETZ, T. Essentials of Social Research. New York: McGrawHill / Open University Press, 2008.

LAGENTE, S. Panorama du Commerce Equitable au Brésil. Campinas, jul. 2005.

LOHBAUER, C. O panorama da citricultura no mundo. Associação Nacional dos Exportadores de Sucos Cítricos. Paraná, 2011. Available at: <http://www.citrusbr.com.br/download/Apresentacao_CitrusBR_Parana17022011.pdf >. Access on: 20 oct., 2012.

MACHADO, M. D.; PAULILLO, L. F.; LAMBERT, A. Comércio Justo Internacional: a inserção da citricultura brasileira. In: PAULILLO, L. F. Agroindústria e citricultura no Brasil: diferenças e dominâncias. Rio de Janeiro: E-papers, 2006.

MAPA. Ministério da Agricultura, Pecuária e Abastecimento. Citrus. Available at: <http://www.agricultura.gov.br/vegetal/culturas/citrus>. Access on: Jan. 25, 2013.

MUCHNIK, J. Localised Agrifood Systems: concept development and diversity of situations. Annual Meetings of the Agriculture, Food, and Human Values.

Proceedings. State College, Pennsylvania, May, 2009.

MUCHNIK, J. Systèmes agroalimentaires localisés: état des recherches et perspectives. Cahiers Agricultures, v. 17, n. 6, nov./dec. 2008.

NEVES, M. F. O retrato da citricultura brasileira. Ribeirão Preto: Marketstrat, 2010.

NEVES, M. F.; TROMBIN, V. G. Análise de uma década na cadeia da laranja. Ribeirão Preto: Marketstrat, 2012.

REDFERN, A.; SNEDKER, P. Creating Market Opportunities for Small Enterprises: experiences of the fair trade movement. Geneva, International Labour Office, 2002.

RIBEIRO, E. P. Ato de Concentração n. 08012.002512/2012-25. Ministério da Justiça. Conselho Administrativo de Defesa da Concorrência. Mar. 2013. 
RINCÓN, J.; DE PAULA, J.; MACHADO, L. A.; VIEIRA, A. Termo de referência Sebrae para o comércio justo . Brasília: Sebrae, 2005. 64p.

SCHERER, F. M.; ROSS, D. Industrial Market Structure and Economic

Performance. Boston: Houghton Mifflin, 1990.

SENHORAS, E. M.; TAKEUCHI, K. P.; TAKEUCHI. K. P. Estrutura da Indústria de Suco de Laranja Concentrado. Uma Investigação do Complexo Agroindustrial Citrícola Paulista. III SEGeT - Simpósio de Excelência em Gestão e Tecnologia. Proceedings. 2006.

TUPY, O.; MANCINELI, C.; COSTA, V. M. H. M. Estratégias produtivas e sustentabilidade de pequenos produtores rurais. $47^{\circ}$ Congress of Sociedade Brasileira de Economia, Administração e Sociologia Rural. Proceedings. Porto Alegre/RS, 2009.

WFTO. World Fairtrade Organization; FLO. Fairtrade Labelling Organization International. A charter of Fairtrade principles. Jan. 2009. Available at: $<$ http://www.fairtradeadvocacy.org/images/stories/FTAO_charters_3rd_version_EN_v1.2.pdf $>$. Access on: Dec. 12, 2012. 